\title{
Efficacy of intermittent or continuous administration of GnRH in inducing ovulation in early and late seasonal anoestrus in the Père David's deer hind (Elaphurus davidianus)
}

\author{
B. J. McLeod* ${ }^{*}$, B. R. Brinklow, J. D. Curlewis $\dagger$ and A. S. I. Loudon
}

* AFRC Institute for Grassland and Animal Production, Hurley, Maidenhead, Berks SL6 5LR, UK; and MRC/AFRC Comparative Physiology Research Group, Institute of Zoology, Regent's Park, London NWI 4RY, UK

Summary. Père David's deer hinds were treated with GnRH, administered as intermittent i.v. injections $(2 \cdot 0 \mu \mathrm{g} /$ injection at 2 -h intervals) for 4 days, or as a continuous s.c. infusion $(1.0 \mu \mathrm{g} / \mathrm{h})$ for 14 days. These treatments were given early (February-March) and late (May-June) in the period of seasonal anoestrus. The administration of repeated injections of $\mathrm{GnRH}$ increased mean $\mathrm{LH}$ concentrations from pretreatment values of $0.54 \pm 0.09$ to $2 \cdot 10 \pm 0.25 \mathrm{ng} / \mathrm{ml}$ over the first $8 \mathrm{~h}$ of treatment in early anoestrus, and from $0.62 \pm 0.11$ to $2.73 \pm 0.49 \mathrm{ng} / \mathrm{ml}$ in late anoestrus. The mean amplitude of GnRH-induced LH episodes was greater $(P<0.01)$ in late $(4.03 \pm 0.28 \mathrm{ng} / \mathrm{ml})$ than in early $(3.12 \pm 0.26 \mathrm{ng} / \mathrm{ml})$ anoestrus, but within each replicate (early or late anoestrus), neither mean LH episode amplitude nor mean plasma LH concentrations differed significantly between the four periods of intensive blood sampling. On the basis of their progesterone profiles, $6 / 12$ hinds had ovulated in response to treatment with injections of GnRH ( $1 / 6$ in early anoestrus and 5/6 in late anoestrus), and oestrus and a preovulatory $\mathrm{LH}$ surge were recorded in all of these animals. Oestrus and a preovulatory LH surge were also recorded in one other animal treated in early anoestrus in which progesterone concentrations remained low. The mean times of onset of oestrus $(91.0 \pm 1.00$ and $62.4 \pm 0.98 \mathrm{~h})$ and of the preovulatory LH surge $(85.8 \pm 3.76$ and $59.4 \pm 0.25 \mathrm{~h})$ both occurred significantly earlier $(P<0.001)$ in animals treated in late anoestrus.

Continuous infusion of GnRH to seasonally anoestrous hinds resulted in an increase in mean plasma $\mathrm{LH}$ concentrations, but this response did not differ significantly between early $(2.15 \pm 0.28 \mathrm{ng} / \mathrm{ml})$ and late $(2.48 \pm 0.26 \mathrm{ng} / \mathrm{ml})$ anoestrus. Ovulation, based on progesterone profiles, occurred in $2 / 7$ hinds in early anoestrus and in $4 / 6$ hinds in late anoestrus. Oestrus was detected in all except one of these hinds. The mean time of onset of oestrus occurred earlier in animals treated in late anoestrus $(66.2 \pm 0.32 \mathrm{~h}$ and $46.7 \pm 0.67 \mathrm{~h}, P<0.01$ ).

The administration of GnRH, given either intermittently or continuously, will induce ovulation in a proportion of seasonally anoestrous Père David's deer. However, more animals ovulate in response to this treatment in late than in early anoestrus ( $75 \%$ compared with $23 \%$ ).

Keywords: deer; anoestrus; GnRH; injection; infusion; ovulation

†Present address: Department of Physiology and Pharmacology, University of Queensland, Brisbane, Queensland 4072, Australia.

†Present address: Invermay Agricultural Centre, Mosgiel, New Zealand. 


\section{Introduction}

The breeding season in the Père David's deer hind has a duration of approximately 160 days, and extends from late summer to mid-winter (Curlewis et al., 1988; Loudon et al., 1989). This pattern of seasonal breeding is similar to that of the sheep, for which it has been proposed that the onset and cessation of seasonal breeding activity is due to changes in the negative feedback action of oestradiol on gonadotrophin secretion. In sheep, this hypothesis is supported by reports of abrupt changes in the frequency of LH episodes that coincide with the seasonal changes in breeding activity (Scaramuzzi \& Baird, 1977; Yuthasastrakosol et al., 1977; McLeod et al., 1982a; I'Anson \& Legan, 1988). However, we have reported changes in the frequency of LH episodes in Père David's deer hinds, over the period of seasonal anoestrus, that differ markedly from those in sheep. In these animals, mean LH episode frequency was low in early anoestrus, increased abruptly in midanoestrus and was maintained at this rate throughout the late anoestrous period (Curlewis et al., 1991). This suggests that seasonal anoestrus in Père David's deer hinds is characterized by an early period of deep anoestrus.

It has been demonstrated, in sheep and cattle, that an increase in LH episode frequency primarily controls the final stages of preovulatory follicle development (Baird, 1978; Rahe et al., 1980). Furthermore, ovulation can be induced in seasonally anoestrous (McLeod et al., 1982a, b) and post-partum anoestrous (Wright et al., 1983) ewes, in prepubertal heifers (McLeod et al., 1985), and post-partum acyclic cows (Walters et al., 1982) and in lactating, seasonally anoestrous goats (Knight et al., 1988) by the administration of repeated injections of GnRH, given to impose artificially a high frequency of $\mathrm{LH}$ episodes. Continuous infusion of $\mathrm{GnRH}$, which results in an elevation in basal LH concentrations rather than an increase in LH episode frequency, also results in the induction of ovulation in anoestrous sheep (McLeod et al., 1983, 1988), but few cattle ovulate in response to this treatment (Jagger et al., 1987, 1989). In the present experiments, seasonally anoestrous Père David's deer hinds were treated with GnRH, given either intermittently or continuously in early and in late seasonal anoestrus, to assess the effectiveness of these treatments in inducing ovulation, and to compare the ovarian and pituitary responses at times when the frequency of endogenous LH episodes is low (early anoestrus) or high (late anoestrus).

\section{Materials and Methods}

\section{Animals and management}

Hand-reared, adult (2-5-year-old) Père David's deer (Elaphurus davidianus) hinds, were treated early and late in the period of seasonal anoestrus. The deer were maintained on pasture (at Whipsnade Park, Beds, UK; latitude $51^{\circ} 30^{\prime} \mathrm{N}$ ) except during the intensive blood-sampling periods (7-10 days), when they were housed indoors under conditions of natural photoperiod and temperature. At these times they were fed hay and pelleted lucerne ad libitum, and had continuous access to fresh water.

\section{Treatment and blood sampling}

Experiment 1. In late February (1987) 6 hinds from a group of 11 animals (mean liveweight $172 \cdot 3 \pm 5.6 \mathrm{~kg}$ ), were pretreated with progesterone for a period of 14 days, adminstered via 5 subcutaneous implants (Sil-Estrus: Ceva Ltd, Sydney, Australia) which were inserted in the flank. Each implant contained $275 \mathrm{mg}$ progesterone in a siliconeelastomer matrix. The animals were sedated ( $20 \mathrm{mg}$ xylazine: Bayer Pharmaceuticals, Leverkusen, West Germany) for implant insertion and removal, and, at the time of implant removal, each hind was fitted with an indwelling jugular vein catheter. Starting approximately $2-4 \mathrm{~h}$ after removal of the progesterone implants, these 6 deer were given i.v. injections of $2.0 \mu \mathrm{g} \mathrm{GnRH}$ (Lutal: Fabwerke Hoechst AG, Frankfurt, West Germany) at 2-h intervals for a period of 4 days. Blood samples $(2.0 \mathrm{ml})$ for $\mathrm{LH}$ determination were taken at $2-\mathrm{h}$ intervals throughout the period of treatment, immediately before each $\mathrm{GnRH}$ injection. In addition, blood samples were taken at 15-min intervals at 0-8, 16-24, 40-48 and 64-72 $\mathrm{h}$ after the first GnRH injection. The remaining 5 animals served as untreated controls.

In early June, the same 11 animals (mean liveweight $167.6 \pm 5.4 \mathrm{~kg}$ ) were subjected to a similar treatment regimen, in which the 6 treated hinds underwent a 12-day period of progesterone treatment ( 5 Sil-Estrus implants), and were 
then subjected to a 4-day period of treatment with the same dose of GnRH given every $2 \mathrm{~h}$. As in the earlier trial, blood samples for LH determination were taken at 2-h intervals throughout the period of GnRH treatment, and at 15-min intervals at $0-8,16-24,40-48$ and $64-72 \mathrm{~h}$ after the first GnRH injection.

The efficacy of the progesterone withdrawal alone to induce ovulation was assessed in these deer by further 12-day periods of progesterone treatment ( 5 Sil-Estrus implants) undertaken in early April and again in early May.

Experiment 2. In late February (1988), a group of 13 hinds (mean liveweight $162.3 \pm 6.1 \mathrm{~kg}$ ) underwent a 12-day period of progestagen pretreatment, during which fluorogestrone acetate was administered via intravaginal sponges (2/animal; Chronogest: Intervet Ltd, Cambridge, UK). At the time of removal of the progestagen sponges, 7 of the deer were sedated (20 mg xylazine) and were fitted with osmotic minipumps (Alzet 2ML2: Alza Corp., Palo Alto, CA, USA), that were placed subcutaneously on the flank under local anaesthesia (lignocaine hypochloride; Lignavet: C-Vet Ltd, Bury St Edmonds, Suffolk, UK) and left in situ for 14 days. The minipumps, which had been preincubated in sterile saline at $37^{\circ} \mathrm{C}$ for $16 \mathrm{~h}$ before insertion, delivered $\mathrm{GnRH}$ at the rate of $1.0 \mu \mathrm{g} / \mathrm{h}$ in $3.77 \mu \mathrm{l} \mathrm{saline}$. The remaining 6 deer received the progestagen treatment alone. Blood samples for $\mathrm{LH}$ determination were collected from all 13 hinds by jugular venepuncture, at 2 -h intervals at $16-22,46-52$ and $76-82 \mathrm{~h}$ after insertion of the minipumps.

In late April, after being randomly re-allocated to treatment $(\mathrm{N}=7)$ or control $(\mathrm{N}=6)$ groups, these 13 hinds were subjected to a progestagen/GnRH treatment regimen and blood-sampling protocol identical to that carried out in February.

All hinds were blood-sampled by jugular venepuncture twice weekly for determination of plasma progesterone concentrations, starting 12 (Exp. 1) or 2 (Exp. 2) weeks before the first GnRH treatment and continuing until 10 (Exps 1 and 2) weeks after the last GnRH treatment, to monitor the onset and the cessation of the breeding season. In addition, blood samples for progesterone determination were taken 3 times weekly for 3 weeks at each of the GnRH treatments, to detect the occurrence of GnRH-induced ovulations.

\section{Detection of oestrus}

Animals were checked at 4-h intervals throughout the periods of GnRH treatment, for signs of behavioural oestrus. Overt oestrus was assessed according to the procedure described by Loudon et al. (1990).

\section{Hormone assays}

Luteinizing hormone. Plasma LH concentrations were measured using the homologous ovine double-antibody radioimmunoassay of Foster \& Crighton (1974), with the modifications described by McLeod et al. (1982a). Validation of this assay for measuring LH in deer has been reported by Loudon et al. (1990). Within this study, the limit of sensitivity of the assay was $0 \cdot 2 \mathrm{ng} \mathrm{NIH-LH}-\mathrm{S} 24$ equivalents/ml plasma, and the intra- and inter-assay coefficients of variation were 8.9 and $9.4 \%$ respectively.

Progesterone. In the first year of the trial, plasma samples were extracted using diethyl ether and progesterone concentrations were determined by the RIA method described by Curlewis et al. (1988). The inter- and intra-assay coefficients of variation were $4.6 \%$ and $10.2 \%$, respectively, and the limit of detection of the assay was $0.2 \mathrm{ng} / \mathrm{ml}$. In the second year, plasma progesterone concentrations were measured using the direct progesterone RIA described for sheep plasma by McNeilly \& Fraser (1987). Serially-diluted plasma samples from individual Père David's deer showed parallelism with the progesterone standard curve which contained charcoal-stripped Père David's deer plasma. Within this study, the limit of detection of the assay was $0.16 \mathrm{ng} / \mathrm{ml}$ and intra-assay coefficient of variation was $8.6 \%$ and $1.7 \%$ at $0.6 \mathrm{ng} / \mathrm{ml}$ and $2.8 \mathrm{ng} / \mathrm{ml}$, respectively. Interassay coefficients of variation were $9 \%$ and $2 \%$ at 0.7 and $2 \cdot 1 \mathrm{ng} / \mathrm{ml}$, respectively $(n=10)$.

\section{Analysis of data}

The definition used to characterize a preovulatory LH surge was that of McLeod et al. (1985), namely that there was (1) a sustained ( $>5-\mathrm{h}$ ) elevation in $\mathrm{LH}$ concentrations above $4.0 \mathrm{ng} / \mathrm{ml}$ and (2) that the peak concentration attained during this time exceeded $10 \mathrm{ng} / \mathrm{ml}$. The onset of this peak was defined at that time when the concentration first exceeded $4.0 \mathrm{ng} / \mathrm{ml}$. An LH episode was defined using the criteria set out by Loudon et al. (1990). The end of the breeding season for an individual hind was taken as the last date on which progesterone concentrations exceeded $0.5 \mathrm{ng} / \mathrm{ml}$, and the onset of the next breeding season as the date on which plasma progesterone concentrations first exceeded $0.5 \mathrm{ng} / \mathrm{ml}$ and remained above that value for at least 7 days. Ovulation was deemed to have occurred in response to treatment if plasma progesterone concentrations increased $(>0.5 \mathrm{ng} / \mathrm{ml})$ and remained elevated for at least 5 days.

Differences in mean LH and progesterone concentrations, and in the time of onset of the preovulatory LH surge, were assessed by analysis of variance, and in the incidence of oestrus, preovulatory surge release of LH and ovulation by $\chi^{2}$ analysis. All results are expressed as mean \pm s.e.m. 


\section{Results}

\section{Experiment 1}

Progesterone profiles. Progesterone profiles extending from early December until late August, and including all of the progesterone and GnRH treatment periods, are shown for all 11 hinds in Fig. 1. There was a high degree of synchrony among animals in both the cessation (6 January $\pm 3 \cdot 2$ days, $\mathrm{N}=11$ ) and the onset ( $20 \mathrm{July} \pm 2 \cdot 2$ days, $N=5$ ) of spontaneously-occurring oestrous cycles (see Fig. 1). Retrospective analysis of progesterone profiles showed that the first GnRH treatment had been carried out at a mean time of $6 \cdot 2 \pm 0.4$ weeks after the end of the last luteal phase of the breeding season, and that the second $\mathrm{GnRH}$ treatment had been given at a mean time of $5.9 \pm 0.3$ weeks before the start of the first luteal phase of the next breeding season.

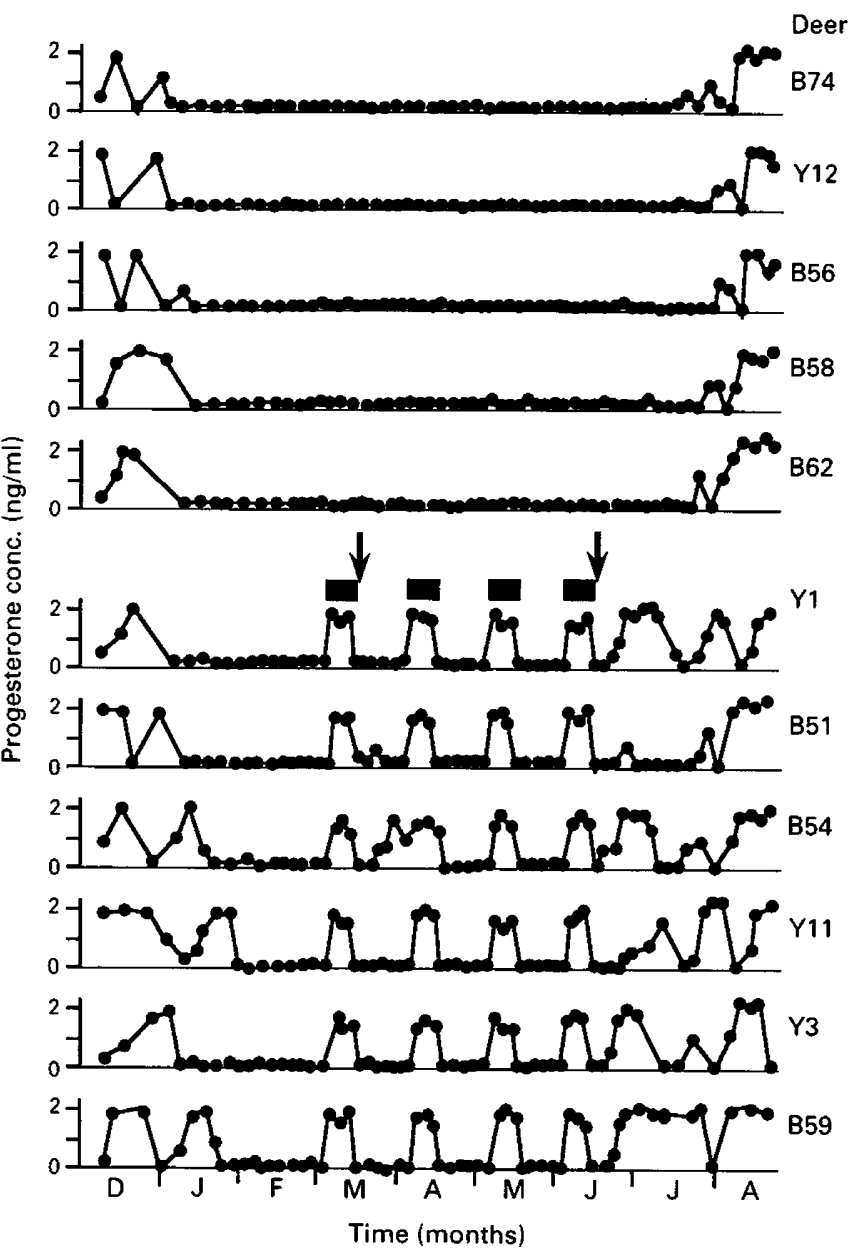

Fig. 1. Plasma progesterone concentrations in Père David's deer hinds (Exp. 1) that were untreated, or were subjected to a period of progesterone treatment with and without subsequent treatment of repeated injections of GnRH $(2.0 \mu \mathrm{g} /$ injection) at $2-\mathrm{h}$ intervals for $96 \mathrm{~h}$. The periods of progesterone treatment are shown by the solid bars and the times of GnRH treatment by the arrows. 
Plasma progesterone concentrations were elevated (mean concentrations $2 \cdot 55 \pm 0 \cdot 15 \mathrm{ng} / \mathrm{ml}$ ) throughout each of the periods that progesterone implants were in situ and fell to basal levels $(<0.5 \mathrm{ng} / \mathrm{ml})$ within 1 day of implant removal. There was an increase in progesterone concentrations, indicative of an induced ovulation, in only 1/6 hinds (Deer B54) treated with GnRH in early anoestrus and this occurred 7 days after the start of treatment. In contrast, an increase in plasma progesterone concentrations occurred in $5 / 6$ hinds in response to GnRH treatment late in the period of seasonal anoestrus. This increase occurred 5 to 7 days after the start of GnRH treatment and progesterone concentrations remained elevated for at least 10 days. On both occasions that the hinds were treated with progesterone implants alone (April and May), plasma progesterone concentrations fell within 1 day of implant removal and remained low $(<0.5 \mathrm{ng} / \mathrm{ml})$ for at least the next 12 days, suggesting that ovulation had not been induced. In the 5 control hinds, plasma progesterone concentrations remained low $(<0.5 \mathrm{ng} / \mathrm{ml})$ throughout the period of seasonal anoestrus. The onset of the breeding season in these 5 hinds was preceded by a 'short' luteal phase of 4-7 days' duration. Similar 'short' luteal phases were recorded after the luteal phase induced by GnRH treatment and before the first normal luteal phase of the breeding season, in $3 / 6$ of the hinds (Deer Y3, B51 and B54) previously with GnRH.

Oestrus. Only $2 / 6$ of the hinds treated with GnRH injections in early anoestrus showed overt oestrus. In these two animals the onset of oestrus occurred $90 \mathrm{~h}$ (Deer B54) and $92 \mathrm{~h}$ (Deer Y3) after the start of $\mathrm{GnRH}$ treatment. When treated with repeated injections of GnRH in late anoestrus, $5 / 6$ hinds displayed oestrus and this occurred at a mean time of $62.4 \pm 1.0 \mathrm{~h}$ after the first GnRH injection, significantly earlier $(P<0.01)$ than that recorded in early anoestrus (Table 1$)$.

Table 1. Mean plasma LH concentrations (based on blood samples taken at 15 -min intervals), the incidence and time of onset of oestrus and the preovulatory LH surge (based on blood samples taken at 2-h intervals) and the incidence of luteal function in seasonally anoestrous Père David's deer treated with repeated injections of $\mathrm{GnRH}(2.0 \mu \mathrm{g} /$ injection) after a 14-day pretreatment period with progesterone implants in early (March) and late (June) anoestrus

\begin{tabular}{|c|c|c|c|c|c|c|c|c|c|c|}
\hline \multirow[b]{2}{*}{$\begin{array}{l}\text { Stage of } \\
\text { anoestrus }\end{array}$} & \multirow[b]{2}{*}{$\mathrm{N}$} & \multicolumn{4}{|c|}{ Plasma LH conc. (ng/ml) } & \multicolumn{2}{|c|}{$\begin{array}{l}\text { Detection of } \\
\text { oestrus }\end{array}$} & \multicolumn{2}{|c|}{$\begin{array}{l}\text { Preovulatory } \\
\text { LH surge }\end{array}$} & \multirow{2}{*}{ 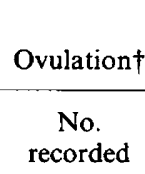 } \\
\hline & & $0-8^{*}$ & $16-24^{*}$ & $40-48^{*}$ & $64-72^{*}$ & $\begin{array}{l}\text { No. } \\
\text { recorded }\end{array}$ & $\begin{array}{l}\text { Time of } \\
\text { onset* }\end{array}$ & $\begin{array}{l}\text { No. } \\
\text { recorded }\end{array}$ & $\begin{array}{l}\text { Time of } \\
\text { onset* }\end{array}$ & \\
\hline $\begin{array}{l}\text { Early } \\
\text { (March) }\end{array}$ & 6 & $\begin{array}{c}2 \cdot 10 \pm \\
0 \cdot 25^{\mathrm{a}}\end{array}$ & $\begin{array}{l}2 \cdot 18 \pm \\
0.35^{\mathrm{a}}\end{array}$ & $\begin{array}{c}1.86 \pm \\
0.29^{\mathrm{a}}\end{array}$ & $\begin{array}{c}1.75 \pm \\
0.69^{\mathrm{a}}\end{array}$ & $2 / 6$ & $\begin{array}{c}91 \cdot 0 \pm \\
1 \cdot 00^{\mathrm{a}}\end{array}$ & $2 / 6$ & $\begin{array}{c}85 \cdot 8 \pm \\
3 \cdot 76^{\mathrm{a}}\end{array}$ & $1 / 6$ \\
\hline $\begin{array}{l}\text { Late } \\
\text { (June) }\end{array}$ & 6 & $\begin{array}{c}2 \cdot 73 \pm \\
0.49^{\mathrm{a}}\end{array}$ & $\begin{array}{r}2.69 \pm \\
0.48^{\mathrm{a}}\end{array}$ & $\begin{array}{c}2 \cdot 33 \pm \\
0.46^{\mathrm{a}}\end{array}$ & $\begin{array}{c}2.03 \pm \\
0.56^{\mathrm{a}}\end{array}$ & $5 / 6$ & $\begin{array}{c}62 \cdot 4 \pm \\
0.98^{\mathrm{b}}\end{array}$ & $5 / 6$ & $\begin{array}{c}59 \cdot 4 \pm \\
0.25^{\mathrm{b}}\end{array}$ & $5 / 6$ \\
\hline
\end{tabular}

Values are mean \pm s.e.m.

*Time in hours from the start of GnRH treatment.

$\doteqdot$ Based on plasma progesterone profiles (see text).

Means with different superscripts are significantly different (a vs b $P<0.01$ ).

Plasma LH concentrations. A profile of plasma LH concentrations is shown in Fig. 2 for one hind (Deer B54) treated with GnRH in late anoestrus. This shows the LH response to each of the GnRH injections administered during the periods of intensive (15-min) blood sampling, and the preovulatory surge that was recorded in this hind. Mean LH concentrations over each of the periods of intensive blood sampling are shown for the GnRH-treated deer in Table 1. In both early and late anoestrus, neither the magnitude of the LH episodes nor the mean LH concentrations recorded in response to $\mathrm{GnRH}$ treatment differed significantly between the 4 periods of intensive blood sampling. Similarly, mean LH concentrations recorded before the start of GnRH treatment (based on only 2 blood samples/hind) did not differ significantly between early $(0.54 \pm 0.09 \mathrm{ng} / \mathrm{ml})$ 
and late $(0 \cdot 62 \pm 0 \cdot 11 \mathrm{ng} / \mathrm{ml})$ anoestrus. However, the mean maximum concentration of GnRHinduced LH episodes was higher $(P<0.05)$ in late than in early anoestrus $(3.12 \pm 0.26 \mathrm{ng} / \mathrm{ml}$ and $4.03 \pm 0.28 \mathrm{ng} / \mathrm{ml}$ in early and late anoestrus, respectively). A preovulatory LH surge (mean maximum concentration $21.6 \pm 5.8 \mathrm{ng} / \mathrm{ml}$ ) was recorded in all 7 of the hinds in which oestrus was detected and this occurred significantly earlier $(P<0.01)$ in late than in early anoestrus $(62.4 \pm 0.98$ and $91.0 \pm 1.00 \mathrm{~h}$ after the start of GnRH treatment). In addition, a preovulatory $\mathrm{LH}$ surge was recorded in more $(P<0.05) \mathrm{GnRH}$-treated hinds in late than in early anoestrus (Table 1).

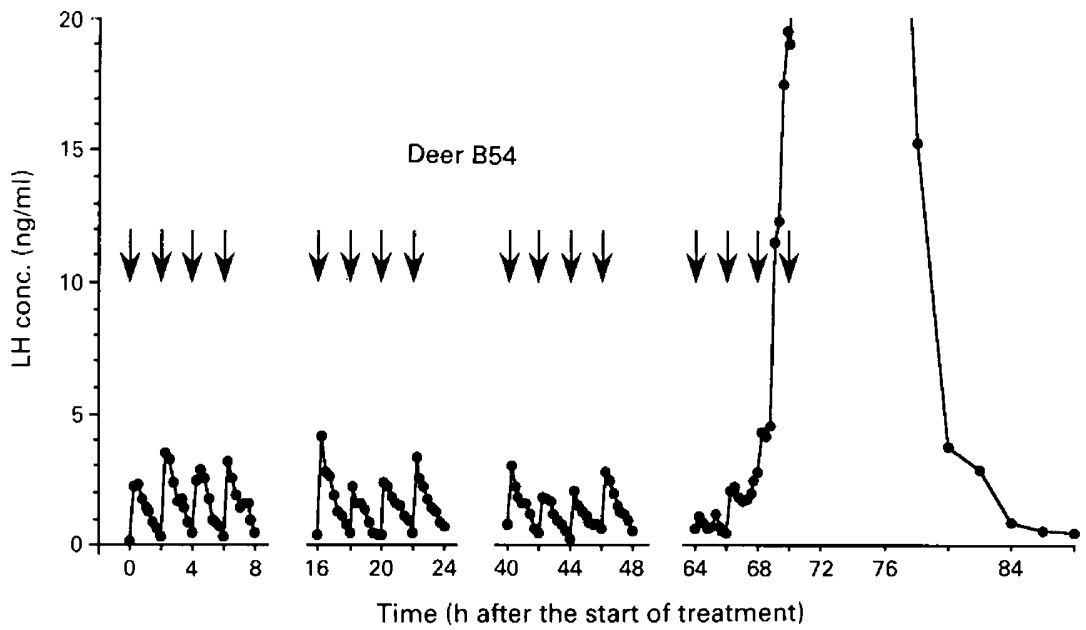

Fig. 2. Plasma LH concentrations over 4 periods of frequent blood sampling (samples taken at 15-min intervals) in a Père David's deer hind treated with repeated injections of GnRH $(2.0 \mu \mathrm{g}$ GnRH at 2-h intervals) for 4 days. The times of GnRH injections are shown by the arrows.

\section{Experiment 2}

Progesterone profiles. Progesterone profiles are shown for all GnRH-treated and control animals in Fig. 3. High concentrations of progesterone had not been recorded in any of the animals before the first GnRH treatment (early March), and no spontaneously-occurring oestrous cycles were recorded until mid-July, 2 months after the end of the second GnRH treatment. There was a significant increase in progesterone concentrations indicative of ovulation in only $2 / 7$ hinds (B51 and B54), following GnRH infusion in early anoestrus. This increase occurred within 7 days of the start of GnRH treatment, and in both these animals progesterone concentrations remained elevated for more than 8 weeks, indicating the presence of persistent corpora lutea. These animals were removed from the analysis of the second GnRH treatment. In 4/6 of those hinds infused with GnRH in late anoestrus, there was an increase in progesterone concentrations within 5 days of the start of treatment, and in all these animals plasma progesterone concentrations remained elevated for at least 10 days.

Oestrus. When GnRH was given by continuous infusion, oestrus was recorded in $3 / 7$ hinds in early anoestrus and in $3 / 6$ in late anoestrus. The mean time of onset of oestrus was significantly earlier $(P<0.05)$ in late than in early anoestrus $(46.1 \pm 2.0$ and $66.2 \pm 0.3 \mathrm{~h}$ after insertion of the osmotic minipumps, respectively). Oestrus was not detected in any of the control animals.

Plasma LH concentrations. Mean plasma LH concentrations for each of the periods of blood sampling are shown in Table 2. Within treatment groups, mean LH concentrations did not differ significantly between sampling periods, or between the two stages of seasonal anoestrus, but at each of the blood-sampling periods, mean LH concentrations were higher $(P<0.001)$ in GnRH-treated than in control animals. 


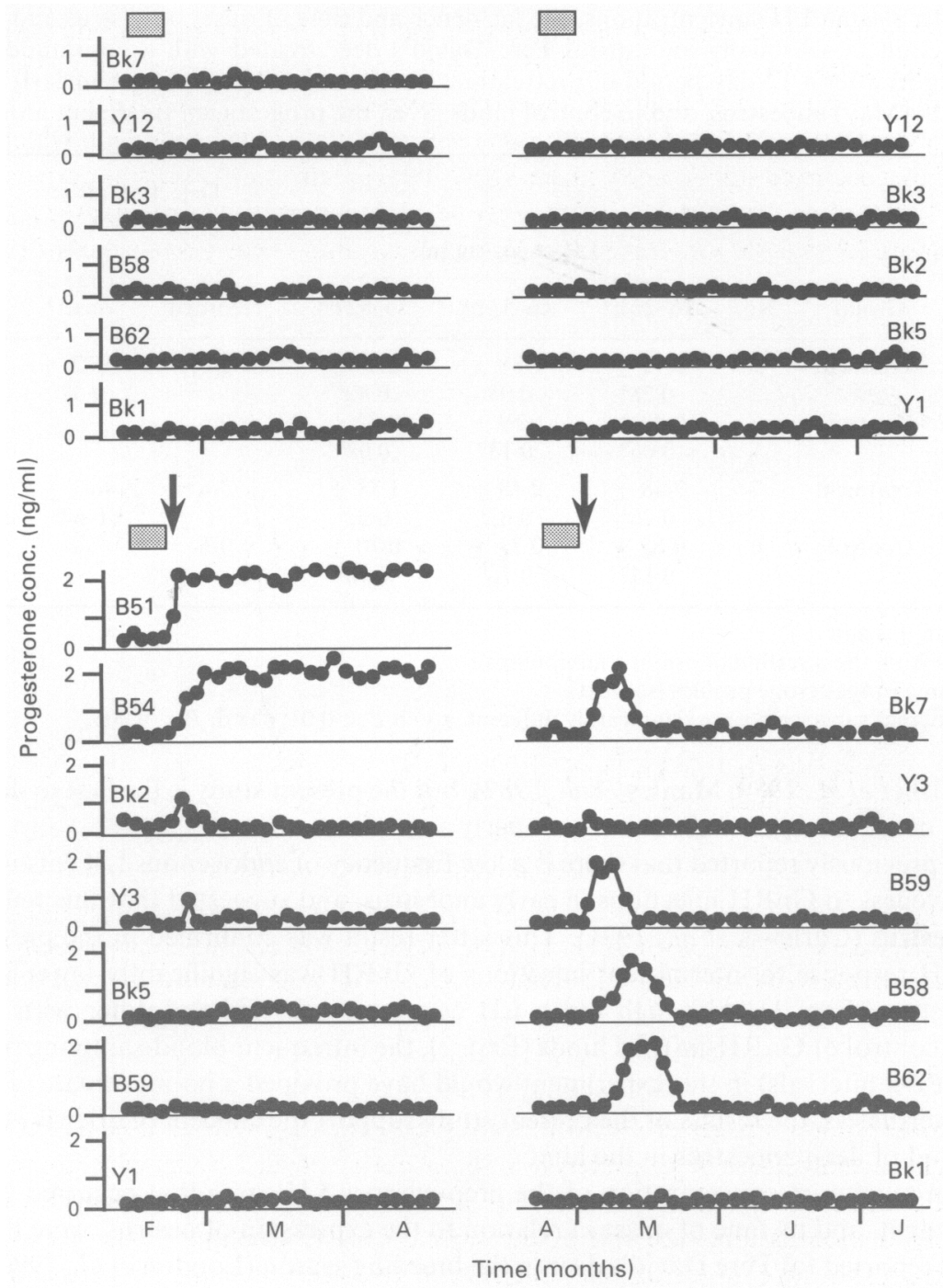

Fig. 3. Plasma progesterone concentrations in Père David's deer hinds (Exp. 2) treated with a continuous infusion of $\mathrm{GnRH}(1.0 \mu \mathrm{g} / \mathrm{h})$ following a period of progestagen pretreatment, or with the progestagen treatment alone. The periods of progestagen treatment are shown by the hatched bars and the times of GnRH treatment by the arrows.

\section{Discussion}

The administration of GnRH to seasonally anoestrous Père David's deer, whether given intermittently or continuously, resulted in an increase in plasma LH concentrations in all animals, and a proportion (33-83\%) showed overt oestrus, preovulatory surge release of LH and an increase in plasma progesterone concentrations indicative of an induced ovulation. When animals from both treatment regimens were combined, more $(P<0.01)$ hinds ovulated in response to GnRH treatment in late anoestrus than in early anoestrus. Irrespective of the mode of GnRH administration, the onset of oestrus occurred approximately $24 \mathrm{~h}$ earlier when treatment was given in late anoestrus. Similar response rates have been achieved in red deer treated with GnRH in late 
Table 2. Mean plasma LH concentrations, the incidence and time of onset of oestrus and the incidence of luteal function in seasonally anoestrous Père David's deer treated with a continuous infusion of $\mathrm{GnRH}(1.0 \mu \mathrm{g} / \mathrm{h})$ after a 12 -day period of pretreatment with progestagen sponges in early (March) and late (May) anoestrus, and in control hinds given the progestagen treatment alone

\begin{tabular}{|c|c|c|c|c|c|c|c|c|}
\hline \multirow[b]{2}{*}{$\begin{array}{l}\text { Stage of } \\
\text { anoestrus }\end{array}$} & \multirow[b]{2}{*}{ Group } & \multirow[b]{2}{*}{ No. } & \multicolumn{3}{|c|}{ LH conc. (ng/ml) } & \multicolumn{2}{|c|}{$\begin{array}{l}\text { Detection of } \\
\text { oestrus }\end{array}$} & \multirow{2}{*}{$\frac{\text { Ovulation } \dagger}{\begin{array}{c}\text { No. } \\
\text { recorded }\end{array}}$} \\
\hline & & & $16-22 \mathrm{~h}^{*}$ & $46-52 h^{*}$ & $76-82 \mathrm{~h}^{*}$ & $\begin{array}{c}\text { No. } \\
\text { recorded }\end{array}$ & $\begin{array}{l}\text { Time of } \\
\text { onset }^{*}\end{array}$ & \\
\hline \multirow[t]{2}{*}{$\begin{array}{l}\text { Early } \\
\text { (March) }\end{array}$} & Treatment & 7 & $\begin{array}{c}2 \cdot 15 \pm \\
0 \cdot 28^{\mathrm{a}}\end{array}$ & $\begin{array}{c}2 \cdot 88 \pm \\
0.95^{\mathrm{a}}\end{array}$ & $\begin{array}{c}2.68 \pm \\
0.82^{\mathrm{a}}\end{array}$ & $3 / 7$ & $\begin{array}{c}66 \cdot 2 \pm \\
0.32^{\mathrm{c}}\end{array}$ & $2 / 7$ \\
\hline & Control & 6 & $\begin{array}{c}0.43 \pm \\
0.06^{\mathrm{b}}\end{array}$ & $\begin{array}{c}0.59 \pm \\
0.13^{\mathrm{b}}\end{array}$ & $\begin{array}{c}0.42 \pm \\
0.08^{\mathrm{b}}\end{array}$ & $0 / 6$ & - & $0 / 6$ \\
\hline \multirow[t]{2}{*}{$\begin{array}{l}\text { Late } \\
\text { (June) }\end{array}$} & Treatment & 7 & $\begin{array}{c}2 \cdot 48 \pm \\
0.26^{\mathrm{a}}\end{array}$ & $\begin{array}{c}2 \cdot 18 \pm \\
0.63^{\mathrm{a}}\end{array}$ & $\begin{array}{c}1.88 \pm \\
0.52^{\mathrm{a}}\end{array}$ & $3 / 6$ & $\begin{array}{c}46 \cdot 7 \pm \\
0 \cdot 67^{\mathrm{d}}\end{array}$ & $4 / 6$ \\
\hline & Control & 6 & $\begin{array}{c}0.65 \pm \\
0.14^{\mathrm{b}}\end{array}$ & $\begin{array}{c}0.73 \pm \\
0.16^{\mathrm{b}}\end{array}$ & $\begin{array}{c}0 \cdot 70 \pm \\
0 \cdot 16^{\mathrm{b}}\end{array}$ & $0 / 5$ & - & $0 / 5$ \\
\hline
\end{tabular}

Values are mean \pm s.e.m.

*Time in hours from the insertion of osmotic minipumps.

†Based on plasma progesterone profiles (see text).

Means with different superscripts are significantly different. a vs b $P<0.01$; c vs d, $P<0.005$.

anoestrus (Fisher et al., 1989; Manley et al., 1989), but the present study is the first to demonstrate a difference in ovarian responsiveness between early and late anoestrus.

We have previously reported that there is a low frequency of endogenous $\mathrm{LH}$ episodes and poor $\mathrm{LH}$ responsiveness to $\mathrm{GnRH}$ injections in early anoestrus, and suggested that this reflected a state of deep anoestrus (Curlewis et al., 1991). This latter result was confirmed in the present study in which the $\mathrm{LH}$ response to intermittent injections of $\mathrm{GnRH}$ was significantly lower in early than in late anoestrus (Exp. 1). Although mean LH concentrations did not differ with the stage of anoestrus in control of GnRH-infused hinds (Exp. 2), the infrequent blood-sampling protocol used (7 samples at 2-h intervals) in this experiment would have provided a poor estimate of $\mathrm{LH}$ concentrations. Nevertheless, the results of the present study support the concept (Curlewis et al., 1991) of an early period of deep anoestrus in the hind.

The mean maximum concentration of the preovulatory LH surge that occurred as a result of GnRH treatment, and its time of onset in relation to the expression of oestrus, were both comparable to those reported for Père David's deer in the breeding season (Loudon et al., 1990). The mean time of onset of oestrus, in relation to the time of progestagen withdrawal, was similar in hinds given repeated injections of GnRH in late anoestrus to that recorded in progestagen-synchronized oestrous cycles in the breeding season (Curlewis et al., 1988). Furthermore, in hinds given GnRH by continuous infusion at the same stage of seasonal anoestrus, the onset of oestrus occurred even earlier. Such variation in the time of onset of the preovulatory LH surge occurs between different breeds of sheep given the same GnRH treatment, and also in the same breed of sheep when treated in different years (Hunter et al., 1986; McLeod et al., 1988). Although there were differences in the time of onset of oestrus between hinds given $\mathrm{GnRH}$ by injection and those given continuous infusion in the present study, as these treatments were not given in the same calendar year, it was not possible to determine whether the differences were due to the different modes of administration, or to different anoestrous seasons.

In the present experiments the occurrence of a GnRH-induced ovulation was defined on the basis of an increase of progesterone concentrations and, as a consequence, the incidence of ovulation may have been underestimated. For example, in sheep it has been demonstrated that a proportion of GnRH-induced ovulations result in corpora lutea that are functionally abnormal and, in these animals, plasma progesterone concentrations remain low (McLeod et al., 1982a, b; 
Hunter et al., 1986). However, it has also been shown in sheep that pretreatment with progesterone before the administration of GnRH ensures that all induced ovulations are functionally competent (McLeod et al., 1982b). In the present study, 2 hinds that were detected in oestrus showed no increase in plasma progesterone concentrations, although a preovulatory LH surge had been recorded in one of these animals. It is possible that these hinds may have ovulated, but despite undergoing a period of progestagen pretreatment, the resultant corpora lutea were functionally abnormal. In contrast, there was an extended luteal phase in $2 \mathrm{GnRH}$-treated hinds (Deer B51 and B54, Exp. 2), indicative of the presence of a persistent corpus luteum. Similar periods of consistently high plasma progesterone concentration have previously been recorded in this species (Curlewis et al., 1988).

The reasons why some hinds fail to respond to treatment are unclear. In view of the changes in the pattern of endogenous LH secretion that occur over the period of seasonal anoestrus, it is possible that the ovarian response to $\mathrm{GnRH}$ is dictated by gonadotrophin concentrations present before the start of treatment. However, mean LH concentrations recorded before administration of the first $\mathrm{GnRH}$ injection did not differ significantly between animals that subsequently showed oestrus $(0.57 \pm 0.08 \mathrm{ng} / \mathrm{ml})$ and those that did not $(0.55 \pm 0.09 \mathrm{ng} / \mathrm{ml})$. Furthermore, the time of onset of oestrus and of the preovulatory LH surge was not related to the LH response to GnRH. An alternative explanation may be that, in addition to the differences in the $\mathrm{LH}$ response to $\mathrm{GnRH}$ and in the frequency of endogenous LH episodes between early and late anoestrus, follicle populations may also differ over the anoestrous period. The absence of large antral follicles at the time of GnRH treatment in early anoestrus may explain the failure of some animals to ovulate in response to treatment, and the longer period of $\mathrm{GnRH}$ stimulation required for those that did ovulate. To date, however, there is no information available regarding follicle populations in anoestrous deer.

In conclusion, this study demonstrates that treatment with $\mathrm{GnRH}$, given as intermittent injections or as a continuous infusion in late anoestrus, induces ovulation in a high proportion of animals, indicating that this technique has potential for use with commercial herds. However, in early anoestrus, GnRH treatment is less efficacious. Further studies are required to establish the relative roles of follicular development and the pituitary response to $\mathrm{GnRH}$ in determining the ovarian response to exogenous GnRH treatment.

We thank Alison Beasey and Barrie Eves for care of the animals; Hoechst A.G., West Germany for the GnRH preparation; NIADDK National Hormone and Pituitary Program for the LH standard; and Dr A. S. McNeilly for the progesterone antiserum.

\section{References}

Baird, D.T. (1978) Evidence in vivo for the two-cell hypothesis of oestrogen synthesis by the sheep Graafian follicle. J. Reprod. Fert. 50, 183-185.

Curlewis, J.D., Loudon, A.S.I. \& Coleman, A.P.M. (1988) Oestrous cycles and the breeding of the Père David's deer hind (Elaphurus davidianus). J. Reprod. Fert. 82, 119-126.

Curlewis, J.D., McLeod, B.J. \& Loudon, A.S.I. (1991) LH secretion and response to GnRH during seasonal anoestrus of the Père David's deer hind (Elaphurus davidianus). J. Reprod. Fert. (in press).

Foster, J.P. \& Crighton, D.B. (1974) Luteinizing hormones (LH) release after single injections of synthetic LH-releasing hormone (LH-RH) in the ewe at three different reproductive stages and comparison with natural LH release at oestrus. Theriogenology 2, 87 100 .
Fisher, M.W., Fennessey, P.E. \& Davis, G.H. (1989) A note on the induction of ovulation in lactating red deer hinds prior to the breeding season. Anim. Prod. 49, $134-138$.

Hunter, M.G., Southee, J.A., McLeod, B.J. \& Haresign, W. (1986) Progesterone pretreatment has a direct effect on GnRH-induced preovulatory follicles to determine their ability to develop into normal corpora lutea in anoestrous ewes. J. Reprod. Fert. 76, 349-363.

I'Anson, H. \& Legan, S.J. (1988) Changes in LH pulse frequency and serum progesterone concentrations during the transition to breeding season in the ewe. J. Reprod. Fert. 82, 341-345.

Jagger, J., Peters, A.R. \& Lamming, G.E. (1987) Hormone responses to low-dose GnRH treatment in post-partum beef cows. J. Reprod. Fert. 80, 263-269. 
Jagger, J., Peters, A.R., McLeod, B.J. \& Lamming, G.E. (1989) Pituitary and ovarian responses to prolonged administration of low doses of $\mathrm{GnRH}$ in prepubertal heifers. Anim. Reprod. Sci. 18, 111-124.

Knight, C.H., McLeod, B.J., Haresign, W. \& Wilde, C.T. (1988) Exogenous GnRH induces ovulation in seasonally anoestrous lactating goats. J. Reprod. Fert. 83, 679-686.

Loudon, A.S.I., Milne, J.A., Curlewis, J.D. \& McNeilly, A.S. (1989) A comparison of the seasonal hormonal changes and patterns of growth, voluntary food intake and reproduction in juvenile and adult red deer (Cervus elaphus) and Père David's deer (Elaphurus davidianus) hind. J. Endocr. 122, 733-745.

Loudon, A.S.I., McLeod, B.J. \& Curlewis, J.D. (1990) Pulsatile secretion of $\mathrm{LH}$ during the periovulatory and luteal phase of the oestrous cycle in the Père David's deer hind (Elaphurus davidianus). J. Reprod. Fert. 89, 663-670.

Manley, T.R., Fisher, M.W., Suttie, J.M. \& Corson, I.D. (1989) Treatment of seasonally anoestrous red deer hinds with GnRH injections for 72 h. Proc. Austr. Soc. Reprod. Biol. 2, p. 129 abstr.

McLeod, B.J., Haresign, W. \& Lamming, G.E. (1982a) The induction of ovulation and luteal function in seasonally anoestrous ewes treated with small-dose multiple injections of GnRH. J. Reprod. Fert. 65, 215-221.

McLeod, B.J., Haresign, W. \& Lamming, G.E. (1982b) Response of seasonally anoestrous ewes to smalldose multiple injections of GnRH with and without progesterone pretreatment. J. Reprod. Fert. 65, 223230.

McLeod, B.J., Haresign, W. \& Lamming, G.E. (1983) Induction of ovulation by continuous infusion of low doses of GnRH. J. Reprod. Fert. 68, 489-495.
McLeod, B.J., Peters, A.R., Haresign, W. \& Lamming, G.E. (1985) Plasma LH and FSH responses and ovarian activity in prepubertal beef heifers treated with repeated injections of low doses of $\mathrm{GnRH}$ for 72 h. J. Reprod. Fert. 74, 589-596.

McLeod, B.J., Haresign, W., Peters, A.R., Humke, R. \& Lamming, G.E. (1988) The development of subcutaneous-delivery preparations of $\mathrm{GnRH}$ for the induction of ovulation in acyclic sheep and cattle. Anim. Reprod. Sci. 17, 33-50.

MeNeilly, A.S. \& Fraser, H.M. (1987) Effect of gonadotrophin-releasing hormone agonist-induced suppression of $\mathrm{LH}$ and FSH on follicle growth and corpus luteum function in the ewe. $J$. Endocr. 115, 273-282.

Rahe, C.H., Owens, R.E., Fleeger, J.L., Newton, H.J. \& Harms, P.G. (1980) Patterns of plasma luteinizing hormone in the cyclic cow; dependence upon the period of the cycle. Endocrinology 107, 489-503.

Scaramuzzi, R.J. \& Baird, D.T. (1977) Pulsatile release of luteinizing hormone and the secretion of ovarian steroids in sheep during anestrus. Endocrinology 101, 1801-1806.

Walters, D.L., Short, R.E., Convey, E.M., Staigmiller, R.B., Dunn, T.G. \& Kaltenbach, C.C (1982) Pituitary and ovarian function in post-partum beef cows. III. Induction of estrus, ovulation and luteal function with intermittent small-dose injections of $\mathrm{GnRH}$. Biol. Reprod. 26, 655-662.

Wright, P.J., Geytenbeck, P.E., Clarke, I.A. \& Findlay, J.K. (1983) LH release and luteal function in postpartum acyclic ewes after pulsatile administration of LH-RH. J. Reprod. Fert. 67, 257-262.

Yuthasastrakosol, P., Palmer, W.M. \& Howland, B.E. (1977) Release of LH in anoestrous and cyclic ewes. J. Reprod. Fert. 50, 319-321.

Received 8 May 1990 